\title{
Article \\ Community Composition and Ex Situ Cultivation of Fungi Associated with UNESCO Heritage Monuments in the Bay of Naples
}

\author{
Mariagioia Petraretti ${ }^{1, *(\mathbb{D}}$, Karl J. Duffy ${ }^{1}$, Angelo Del Mondo ${ }^{1,2} \mathbb{( D}$, Antonino Pollio ${ }^{1}$ and Antonino De Natale ${ }^{1}$ \\ 1 Dipartimento di Biologia, Università di Napoli Federico II, Complesso Universitario Monte S. Angelo, \\ Via Cintia 4, 80126 Napoli, Italy; karljoseph.duffy@unina.it (K.J.D.); angelo.delmondo@szn.it or \\ angelo.delmondo@unina.it (A.D.M.); antonino.pollio@unina.it (A.P.); denatale@unina.it (A.D.N.) \\ 2 Stazione Zoologica Anton Dohrn, Istituto Nazionale Di Biologia, Ecologia e Biotecnologie Marine, \\ Villa Comunale, 80121 Napoli, Italy \\ * Correspondence: mariagioia.petraretti@unina.it
}

check for updates

Citation: Petraretti, M.; Duffy, K.J.; Del Mondo, A.; Pollio, A.; De Natale, A. Community Composition and Ex Situ Cultivation of Fungi Associated with UNESCO Heritage Monuments in the Bay of Naples. Appl. Sci. 2021, 11,4327. https://doi.org/10.3390/ app11104327

Academic Editors: Filomena De Leo and Daniela Isola

Received: 12 March 2021

Accepted: 6 May 2021

Published: 11 May 2021

Publisher's Note: MDPI stays neutral with regard to jurisdictional claims in published maps and institutional affiliations.

Copyright: (c) 2021 by the authors. Licensee MDPI, Basel, Switzerland. This article is an open access article distributed under the terms and conditions of the Creative Commons Attribution (CC BY) license (https:/ / creativecommons.org/licenses/by/ $4.0 /)$.

\begin{abstract}
The Bay of Naples, Italy, is renowned for its archaeological heritage. However, this heritage is threatened by the combination of weathering and the biological activity of microorganisms. Fungi are among the major agents of microbial deterioration of cultural heritage since they can cause cracks and lesions in monuments due to the penetrating force of their hyphae. Such biodeterioration may weaken the stone structures and threaten the longevity of these culturally important monuments. To address this, we collected, identified, and maintained in culture filamentous fungi that colonize the external surface of monuments at five important archaeological sites near Naples, namely Cuma, Ercolano, Nola, Oplonti, and Pompei. We isolated a total of 27 fungal taxa, all of which can be cultivated in the laboratory, and form a part of our reference collection. Many of the described fungal taxa we found belong to groups that are involved in stone biodeterioration and can thus be considered as model organisms for in vitro studies. These results emphasize the importance of identifying and cultivating fungal stock cultures for non-invasive studies on biodeterioration. Our newly developed reference collection represents a useful resource that is available to other researchers to rapidly identify potentially hazardous fungi on other monuments.
\end{abstract}

Keywords: fungi; ex situ collection; biodeterioration; biodegradation; cultural heritage

\section{Introduction}

Fungi play an important role in the deterioration of buildings. Deterioration caused by fungal colonization involves both physical and chemical damage of stone surfaces, and in most cases, they take place simultaneously [1]. Physical damage is related to the ability of fungal hyphae to penetrate into the substratum, where pores and fissures provide a useful microhabitat for fungal growth. The pressure exerted by fungal growth leads to further damage due to cell turgor pressure and exopolysaccharide formation that, in addition to fungal adhesion on stone surfaces, increases mechanical pressure [2]. Moreover, chemical damage occurs due to byproducts of fungal metabolism that leads to corrosion and discoloration of stone surfaces. Fungi are able to excrete a large variety of organic acids that act as metal-chelators [3] and mediate the precipitation of secondary minerals produced through the reaction of anions from excreted acids with cations from the stone. The formation of secondary minerals, such as carbonates, oxalates, and phosphates, can cause blistering, scaling, granular disintegration, and flaking or "spalling" of outer layers, leading to stone decay [4]. There is a close relationship between material and colonizing organisms [5]; indeed, the degree of fungal colonization of a stone surface also depends on the structure, wetness, and chemical and mineralogical compositions of the substrata as well as environmental conditions [6,7]. Different lithotypes, e.g., brick, limestone, marble, 
tuff, and porphyry, provide a diverse range of substrates that fungi may use to acquire nutrients and grow.

Despite the large number of studies in the literature in which damage to cultural heritage is directly associated with fungi colonization, the occurrence of fungi on cultural heritage monuments does not necessarily mean that these fungi cause the loss of chemical and physical properties of the substrate; indeed, filamentous fungi as well as lichens could protect colonized materials, especially against environmental parameters [8], or they could bear no influence on the material properties. The multifaceted role of fungi in biodeterioration can be effectively assessed on the basis of preliminary in vitro tests, particularly recommended in the issues of monument protection, that require ex situ conservation strategies for fungal strains isolated from monuments. Ex situ collections may significantly improve our knowledge of the role of fungi in stone cultural heritage biodeterioration, providing the basis for an appropriate and effective maintenance and restoration strategy. The importance of maintaining a broad range of taxa in collections for ex situ conservation accessible to researchers prompted us to perform a survey campaign along the archaeological remains of Campania, Italy. Campania hosts a large number of works of art and monuments made of different stone materials, spanning the last three thousand years. Despite this unique cultural heritage, a deep sampling aimed to assess the biodiversity of cultivable fungi in these historical areas has never been conducted.

Using a combination of microscopical, genetic, and culture techniques, here we describe the taxonomic diversity of fungi that occur in the UNESCO heritage sites of Cuma, Ercolano, Nola, Oplonti, and Pompei, with the overall aim of developing an ex situ collection of fungal strains from these archeological sites.

\section{Materials and Methods}

\subsection{Sampling}

The sampling campaign in this study was carried out in March 2018 at some of the most important cultural heritage sites in Campania, namely the Sibyl Caves in Cuma, the Suburban Baths in Ercolano, the Roman Amphitheater in Nola, the House of Poppea in Oplonti, and the House of Fauno and the House of Castricio in Pompei (Figure 1).

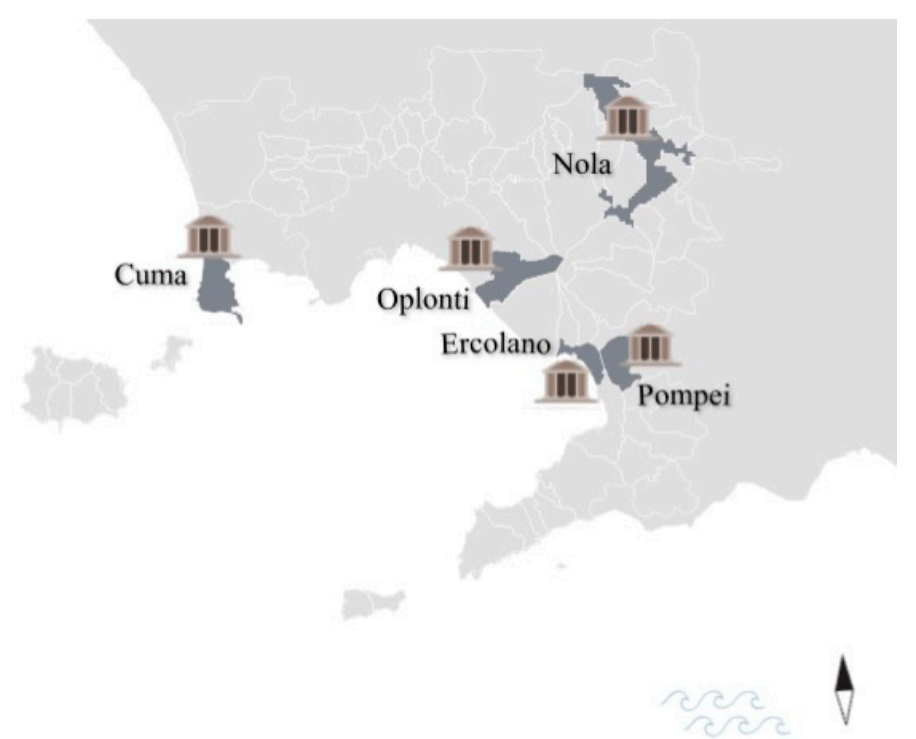

Figure 1. Location of the sampling site of UNESCO heritage monuments in the bay of Naples, Campania, Italy.

At every site, we measured ecological parameters, e.g., temperature and relative humidity, using a thermo-hygrometer (model HI 9564, Hanna ${ }^{\circledR}$ Instruments, Smithfield, RI, USA) and light intensity using a Climalux N light meter (Laboratori di Strumentazione 
Industriale S.p.a., Milan, Italy). We measured $\mathrm{pH}$ on substrates at sampling points using a $\mathrm{pH}$ test paper strip. All the environmental parameters are shown in Table 1. The sampling points were chosen on the basis of the visibility of the fungal presence on the surface. Biofilm samples were taken by gently scraping the walls of the sampling sites with a sterile scalpel and adhesive tape strips were also used as a non-destructive sampling method [9]. The materials were deposited into sterile vials, until arrival at the laboratory.

Table 1. Values of environmental parameters (light, $\mathrm{pH}$, relative humidity, and temperature) at each sampling site.

\begin{tabular}{|c|c|c|c|c|}
\hline Location & Light $\left(\mu \mathrm{mol} \mathrm{m} \mathrm{m}^{-2} \mathrm{~s}^{-1}\right)$ & $\mathrm{pH}$ & Relative Humidity & Temperature $\left({ }^{\circ} \mathrm{C}\right)$ \\
\hline $\begin{array}{l}\text { Cuma, Sibyl } \\
\text { Caves }\end{array}$ & $0.8 \pm 0.01$ & $7 / 8$ & $50 \pm 1.2 \%$ & $19.2 \pm 0.3$ \\
\hline $\begin{array}{c}\text { Ercolano, } \\
\text { Suburban Baths }\end{array}$ & $30 \pm 0.6$ & $7 / 8$ & $94 \pm 1.7 \%$ & $15.3 \pm 0.9$ \\
\hline $\begin{array}{l}\text { Nola Roman } \\
\text { Amphitheater }\end{array}$ & 130.84 & $7 / 8$ & $90 \pm 1.2 \%$ & $16.7 \pm 1.2$ \\
\hline $\begin{array}{c}\text { House of } \\
\text { Poppea, Oplonti }\end{array}$ & 129.95 & $7 / 8$ & $95 \pm 0.9 \%$ & $13.2 \pm 0.9$ \\
\hline $\begin{array}{l}\text { House of Fauno, } \\
\text { Pompei }\end{array}$ & $46 \pm 0.6$ & $7 / 8$ & $58.8 \pm 0.9 \%$ & $18.2 \pm 0.9$ \\
\hline $\begin{array}{l}\text { House of } \\
\text { Castricio, } \\
\text { Pompei }\end{array}$ & 8.97 & $7 / 8$ & $90 \pm 1.2 \%$ & $18.3 \pm 0.9$ \\
\hline
\end{tabular}

\subsection{Confocal Laser Scanning Microscope Analysis}

The recorded adhesive tape samples were cut into small sections (approximately $1 \times 1 \mathrm{~cm},[9])$, placed on a glass slide, and observed on a Confocal Laser Scanning Microscope (CLSM), Zeiss LSM 700 (Carl Zeiss AG, Munich, Germany, using the software Zen $2011)$, by capturing images with a $63 \times$ water immersion objective. Images were acquired in three channels simultaneously: the red channel was used to discriminate phototrophs containing autofluorescence pigments (chlorophyll a and phycobilins), with excitation beams at 488 and $639 \mathrm{~nm}$ and emissions at 590-800 nm; the green channel was used to detect extrapolymeric matrix (EPS) using concanavalin-A with Alexa 488, with the excitation beams at $488 \mathrm{~nm}$ and emissions at 553-636 nm; and calcofluor-white was used to evidence the bacteria and hyphae with the excitation beams at 405 and $488 \mathrm{~nm}$ and emissions at 415-506 nm (blue channel) [10].

\subsection{Isolation of Fungal Strains}

After the sampling campaign, samples were inoculated on agar medium, such as Potato Dextrose Agar (PDA) prepared according to Samson et al. [11], Bold's Basal Medium (BBM) [12] added to sucrose (12 g/L) according to Jeger et al. [13], and Malt-Yeast ExtractSucrose Agar (MEA, Difco ${ }^{\mathrm{TM}}$ ) prepared according to Skaar and Stenwig [14]. Incubation was carried out at $22 \pm 2{ }^{\circ} \mathrm{C}$ for 30 days. At the end of the incubation period, enumeration of microorganisms as cfu/g of sample was carried out and the several mycelia obtained were isolated with the aid of a stereomicroscope. Afterwards, fungi were separately cultivated on PDA and finally observed with a stereomicroscope.

\subsection{Identification of Fungal Isolates}

Fungal strains were identified through a polyphasic approach that is an integrated approach of identification based on morphological and molecular features of microorganisms [15]. According to Barnett and Hunter [16] and Fassatiovà and Ellis [17], the morphological identification of fungi was based on the macroscopic features of colonies growing on agar plates and the micromorphology of the reproductive structure. The morphological analysis was then confirmed by molecular analysis. For each fungal isolate, the following procedure was applied: DNA was extracted with a modified DNA extraction 
protocol [18] and used for a Polymerase Chain Reaction with primers targeting the internal transcribed spacer region (ITS) (primer forward, 5'-TCCGTAGGTGAACCTGCGG-3'; primer reverse, $5^{\prime}$-TTCAAAGATTCGATGATTCAC-3'). The ITS is the region spanning ITS1, 5.8S rRNA, and ITS2 was recently elected to be the universal barcode marker for fungi [19]. This DNA region has enough gaps between the intraspecific and interspecific variation across the kingdom Fungi and has been shown to have a high amplification success rate in various fungal taxa, e.g., it can discriminate the majority of species in Mucorales [20]. The barcode region together with a well-curated database of DNA sequences may constitute a reliable and fast tool for culture collection in the task of providing certification of fungal cultures. The amplification reaction was carried out in a reaction volume of $25 \mu \mathrm{L}$ containing $2.5 \mu \mathrm{L}$ of $10 \times$ reaction buffer, $1.5 \mu \mathrm{L}$ of $\mathrm{MgCl}_{2}, 2 \mu \mathrm{L}$ of dNTP, $1.5 \mu \mathrm{L}$ of each of the primers, and $0.2 \mu \mathrm{L}$ of Taq polymerase (EconoTaq, Lucigen, Middleton, WI, USA). An amount of DNA, approximately $100 \mathrm{ng}$, was added to each reaction mixture in a PCR tube. The profile used was the same described by Del Mondo 2017 [21]. Amplification was run in an Applied Biosystem 2720 thermal cycler. The amplification product was then evaluated on $1.2 \%(w / v)$ agarose gel in an electrophoretic purified with a QIAquick ${ }^{\circledR}$ PCR Purification kit (Qiagen Inc, Valencia, CA, USA). The sequence reaction was obtained with the BigDye Terminator Cycle Sequencing technology (Applied Biosystems, Foster City, CA, USA), purified automatically using the Agencourt CleanSEQ Dye terminator removal Kit (Agencourt Bioscience Corporation, 500 Cummins Center, Suite 2450, Beverly, MA, USA) and a robotic station Biomek FX (Beckman Coulter, Fullerton, CA, USA). The product was analyzed on an Automated Capillary Electrophoresis Sequencer 3730 DNA Analyzer (Applied Biosystems). The amplification primers were used as the sequencing primers. The obtained sequence was searched for in BLAST version 2.0 (National Center for Biotechnology Information databases) and identified. The ITS sequences obtained in this study have been deposited in GenBank (the accession numbers are listed in Table 2).

Table 2. Identification of the fungal species complex level based on ITS sequences with the description of their sampling site and lithic substrate. ACUF Collection Codes and Gene Bank Accession numbers are given for each strain.

\begin{tabular}{|c|c|c|c|c|}
\hline $\begin{array}{c}\text { Identified Species } \\
\text { Complex Level }\end{array}$ & Sites & Source & $\begin{array}{c}\text { ACUF } \\
\text { Collection Code }\end{array}$ & $\begin{array}{c}\text { Gene Bank } \\
\text { Accession Number }\end{array}$ \\
\hline \multirow[t]{2}{*}{$\begin{array}{c}\text { Alternaria section } \\
\text { Alternata }\end{array}$} & Pompei & Mortar & $033 \mathrm{f}$ & MW881067 \\
\hline & Pompei & Mortar & $032 f$ & MW881066 \\
\hline $\begin{array}{c}\text { Alternaria section } \\
\text { Alternata }\end{array}$ & Nola & Marble & $053 \mathrm{f}$ & MW881087 \\
\hline $\begin{array}{c}\text { Alternaria section } \\
\text { Alternata }\end{array}$ & Ercolano & Plaster & $017 f$ & MW881054 \\
\hline Alternaria sp. & Ercolano & Mortar & 020f & MW881053 \\
\hline $\begin{array}{c}\text { Aspergillus section } \\
\text { Aeni }\end{array}$ & Pompei & Mortar & $039 f$ & MW881073 \\
\hline $\begin{array}{c}\text { Aspergillus section } \\
\text { Usti }\end{array}$ & Ercolano & Mortar & $029 f$ & MW881060 \\
\hline \multirow[t]{2}{*}{$\begin{array}{c}\text { Aspergillus section } \\
\text { Usti }\end{array}$} & Cuma & Tuff & $012 f$ & MW881047 \\
\hline & Cuma & Tuff & $022 f$ & MW881049 \\
\hline \multirow[t]{2}{*}{$\begin{array}{c}\text { Aspergillus section } \\
\text { Nigri }\end{array}$} & Ercolano & Plaster & $007 f$ & MW881065 \\
\hline & Ercolano & Plaster & $019 \mathrm{f}$ & MW881062 \\
\hline
\end{tabular}


Table 2. Cont.

\begin{tabular}{|c|c|c|c|c|}
\hline $\begin{array}{l}\text { Identified Species } \\
\text { Complex Level }\end{array}$ & Sites & Source & $\begin{array}{c}\text { ACUF } \\
\text { Collection Code }\end{array}$ & $\begin{array}{c}\text { Gene Bank } \\
\text { Accession Number }\end{array}$ \\
\hline \multirow[t]{2}{*}{$\begin{array}{l}\text { Aspergillus section } \\
\text { Circumdati }\end{array}$} & Pompei & Frescos & $015 f$ & MW881099 \\
\hline & Pompei & Frescos & $026 f$ & MW881100 \\
\hline Aspergillus sp. & Cuma & Tuff & $008 \mathrm{f}$ & MW881051 \\
\hline Cladosporium sp. & Pompei & Mortar & $041 \mathrm{f}$ & MW881075 \\
\hline \multirow[t]{4}{*}{ Clonostachys sp. } & Oplonti & Mortar & $005 f$ & MW881093 \\
\hline & Oplonti & Mortar & $056 f$ & MW881095 \\
\hline & Oplonti & Mortar & $010 f$ & MW881098 \\
\hline & Oplonti & Mortar & $021 \mathrm{f}$ & MW881097 \\
\hline \multirow[t]{3}{*}{ Clonostachys sp. } & Nola & Marble & $042 f$ & MW881076 \\
\hline & Nola & Marble & $043 \mathrm{f}$ & MW881077 \\
\hline & Nola & Marble & $044 \mathrm{f}$ & MW881078 \\
\hline $\begin{array}{l}\text { Curvularia geniculata } \\
\text { species complex }\end{array}$ & Ercolano & Plaster & $023 f$ & MW881052 \\
\hline $\begin{array}{l}\text { Fusarium oxysporum } \\
\text { species complex }\end{array}$ & Ercolano & Plaster & 031f & MW881064 \\
\hline $\begin{array}{l}\text { Fusarium section } \\
\text { Discolor }\end{array}$ & Cuma & Tuff & $009 \mathrm{f}$ & MW881048 \\
\hline $\begin{array}{l}\text { Fusarium oxysporum } \\
\text { species complex }\end{array}$ & Pompei & Frescos & $014 \mathrm{f}$ & MW881102 \\
\hline \multirow[t]{4}{*}{$\begin{array}{l}\text { Fusarium oxysporum } \\
\text { species complex }\end{array}$} & Ercolano & Plaster & $018 \mathrm{f}$ & MW881055 \\
\hline & Ercolano & Plaster & $024 \mathrm{f}$ & MW881056 \\
\hline & Ercolano & Plaster & $025 f$ & MW881057 \\
\hline & Ercolano & Plaster & $028 \mathrm{f}$ & MW881059 \\
\hline \multirow[t]{3}{*}{$\begin{array}{l}\text { Fusarium oxysporum } \\
\text { species complex }\end{array}$} & Oplonti & Mortar & $054 \mathrm{f}$ & MW881090 \\
\hline & Oplonti & Mortar & $055 \mathrm{f}$ & MW881091 \\
\hline & Oplonti & Mortar & $001 \mathrm{f}$ & MW881089 \\
\hline $\begin{array}{l}\text { Fusarium solani } \\
\text { species complex }\end{array}$ & Ercolano & Plaster & $016 f$ & MW881063 \\
\hline Fusarium sp. & Oplonti & Mortar & $006 f$ & MW881088 \\
\hline $\begin{array}{c}\text { Fusarium tricinctum } \\
\text { species complex }\end{array}$ & Oplonti & Mortar & $002 \mathrm{f}$ & MW881094 \\
\hline Lecanicillium sp. & Pompei & Frescos & $013 f$ & MW881101 \\
\hline Lecanicillium sp. & Ercolano & Mortar & $027 f$ & MW881058 \\
\hline Lecanicillium sp. & Ercolano & Plaster & 030f & MW881061 \\
\hline $\begin{array}{l}\text { Neofusicoccum } \\
\text { parvum species } \\
\text { complex }\end{array}$ & Cuma & Tuff & $011 \mathrm{f}$ & MW881050 \\
\hline \multirow[t]{3}{*}{$\begin{array}{l}\text { Penicillium section } \\
\text { Fasciculata }\end{array}$} & Pompei & Mortar & $036 f$ & MW881070 \\
\hline & Pompei & Mortar & $038 \mathrm{f}$ & MW881072 \\
\hline & Pompei & Mortar & $035 \mathrm{f}$ & MW881069 \\
\hline
\end{tabular}


Table 2. Cont.

\begin{tabular}{|c|c|c|c|c|}
\hline $\begin{array}{l}\text { Identified Species } \\
\text { Complex Level }\end{array}$ & Sites & Source & $\begin{array}{c}\text { ACUF } \\
\text { Collection Code }\end{array}$ & $\begin{array}{c}\text { Gene Bank } \\
\text { Accession Number }\end{array}$ \\
\hline & Pompei & Mortar & 040f & MW881074 \\
\hline \multirow[t]{2}{*}{ Penicillium sp. } & Pompei & Mortar & $034 \mathrm{f}$ & MW881068 \\
\hline & Pompei & Mortar & $037 f$ & MW881071 \\
\hline \multirow[t]{5}{*}{$\begin{array}{l}\text { Penicillium section } \\
\text { Aspergilloides }\end{array}$} & Nola & Marble & $046 f$ & MW881080 \\
\hline & Nola & Marble & $047 f$ & MW881081 \\
\hline & Nola & Marble & $048 \mathrm{f}$ & MW881082 \\
\hline & Nola & Marble & $049 f$ & MW881083 \\
\hline & Nola & Marble & $051 \mathrm{f}$ & MW881085 \\
\hline Purpureocillium sp. & Oplonti & Frescos & $004 \mathrm{f}$ & MW881096 \\
\hline $\begin{array}{c}\text { Talaromyces section } \\
\text { Talaromyces }\end{array}$ & Oplonti & Mortar & $003 f$ & MW881092 \\
\hline $\begin{array}{c}\text { Talaromyces section } \\
\text { Talaromyces }\end{array}$ & Nola & Marble & $045 \mathrm{f}$ & MW881079 \\
\hline \multirow[t]{2}{*}{ Trichoderma sp. } & Nola & Marble & $050 f$ & MW881084 \\
\hline & Nola & Marble & $052 \mathrm{f}$ & MW881086 \\
\hline
\end{tabular}

\subsection{Fungal Preservation for Ex Situ Conservation}

In according to the World Federation for Culture Collection Guidelines, more than one method was applied for each fungal strain for successful preservation. Our fungal strains are stored by different methods: (a) PDA on Petri dishes at a temperature range of between $22{ }^{\circ} \mathrm{C}$ and $25{ }^{\circ} \mathrm{C}$ in darkness; (b) in a corked glass tube with sterilized water at room temperature [22]; and (c) at $-80^{\circ} \mathrm{C}$ in glycerol (selected strains only). This method, namely cryopreservation together with freeze drying, is considered to be a long-term preservation method [23]. To maintain fungi in a viable state, to evaluate purity, and to avoid devitalization, monthly checking and refreshment of cultures were performed. All the fungal strains are maintained in the Algal Culture Collection (ACUF) at the Department of Biology, University of Naples Federico II, Italy. This collection, traditionally devoted to the maintenance of aero-terrestrial microalgae and cyanobacteria [24], has been enriched with a special section devoted to the maintenance of fungal strains isolated directly from archeological sites in Campania. Each strain is included in a private database with all the information regarding sampling sites, origin substrate, data on collection, ecological notes, cultivation and maintenance methods, phenotypic characteristics, and genomic analysis. In order to maintain the safety of the data associated with each of the strains preserved in the collection, all computer files are duplicated and kept in a separate area. Furthermore, we deposited our isolates at the Mycotheca Universitatis Taurinensis, Turin, Italy (MUT), a renowned collection specialized in fungal preservation.

\section{Results}

\subsection{Description of Damage and Substrate Change}

Biological growth on stone can result in changes in surface color and structure depending on the identity of the organism and their growth and behavior. At our sampling sites, the biological colonization on stone surfaces assumed the forms of epilithic formations with a patina aspect. In particular, these organisms formed a subaerial biofilm, which is a type of biofilm that occurs at the atmosphere-rock interface. This type of biofilm has been frequently reported in the literature on hypogean monuments, such as catacombs [25], and on walls, statues, and wetlands. These formations may have a colored patinas aspect, depending on the type of biocenosis and of the growth phase of the prevailing species. As 
shown in Figure $2 b, d, e$, the stone surface appears with a green and greenish stain, probably due to the presence of organic pigments (e.g., chlorophylls, carotenoids, melanins) [26]. In Figure $2 \mathrm{~h}, \mathrm{k}, \mathrm{n}$, the stone surface appears with a black stain and this is related to the mixed association of different fungal groups.

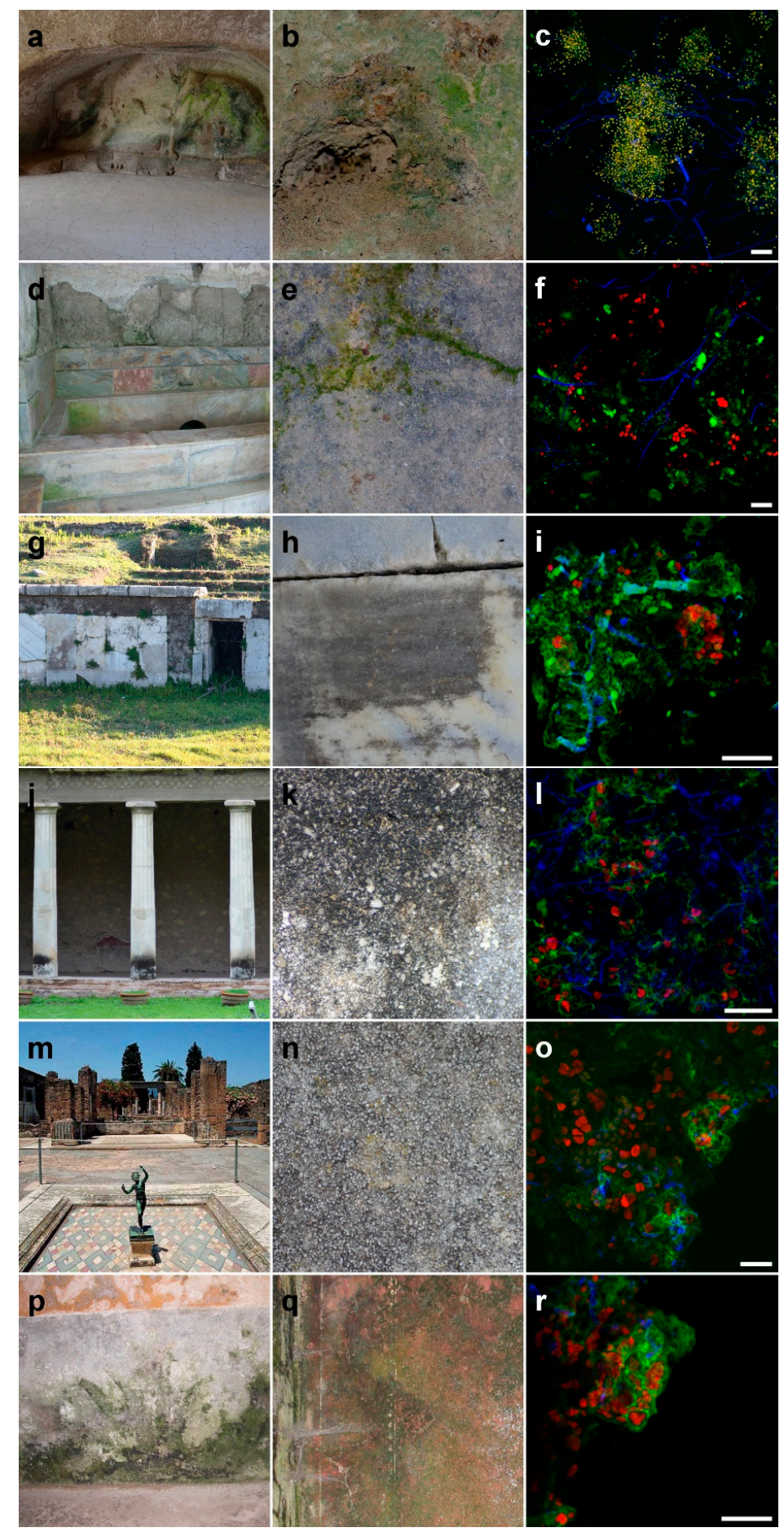

Figure 2. Archeological sites: Sibyl Caves in Cuma (a), Suburban Baths in Ercolano (d), the Roman Amphitheater in Nola (g), the House of Poppea in Oplonti (j), and the House of Fauno (m) and the House of Castricio (p) in Pompei; the visible alteration at the same sites $(\mathbf{b}, \mathbf{e}, \mathbf{h}, \mathbf{k}, \mathbf{n}, \mathbf{q})$; the recorded adhesive tape samples observed on the CLSM (c, $\mathbf{f}, \mathbf{i}, \mathbf{l}, \mathbf{o}, \mathbf{r}$; scale bar, $50 \mu \mathrm{m})$. 


\subsection{Confocal Laser Microscopy}

All the samples analyzed by CLSM revealed that many cells contained chlorophyll and phycobilin (red auto-fluorescence), which were ascribed to algae and cyanobacteria and polysaccharide polymers (e.g., cellulose and chitin) in their cell walls (blue color), which were ascribed to fungi (Figure $2 \mathrm{c}, \mathrm{f}, \mathrm{i}, \mathrm{l}, \mathrm{o}, \mathrm{r}$ ).

\subsection{Molecular Identifications}

Table 2 shows the identification of the isolated fungal species retrieved from the sampled UNESCO monuments, together with sites and source sampled as well as the collection code linked to the fungal strains and the GenBank accession numbers of the obtained sequences.

A total of 18 fungal taxa, belonging to 3 different Classes, 5 different Orders, and 10 different Families, were obtained (Figure 3 ) and kept in culture.

A

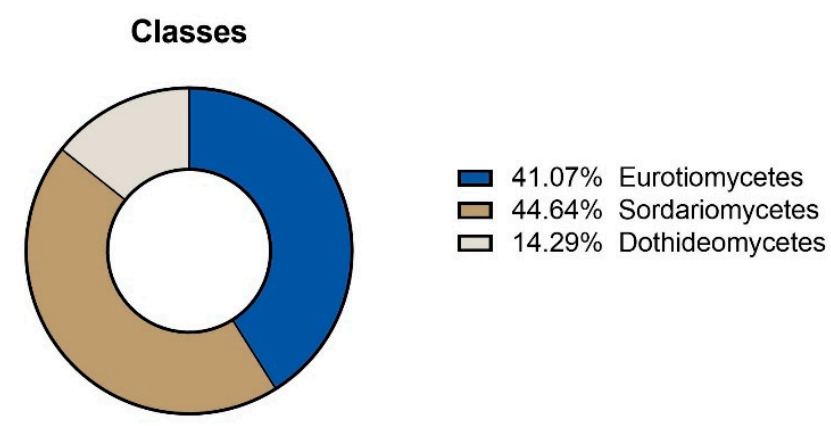

B

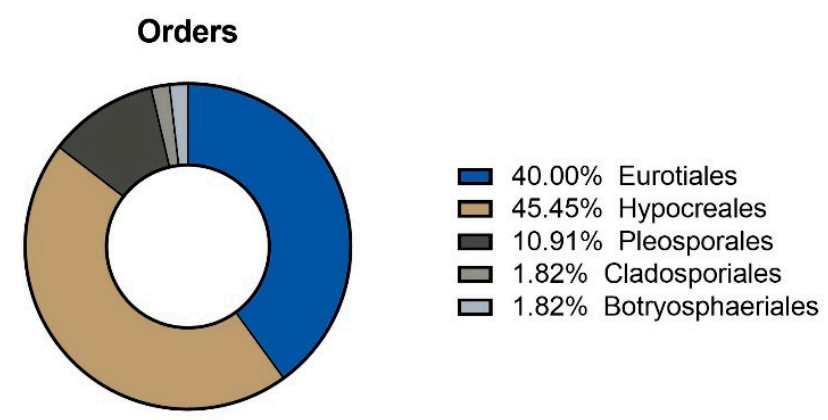

C

Families

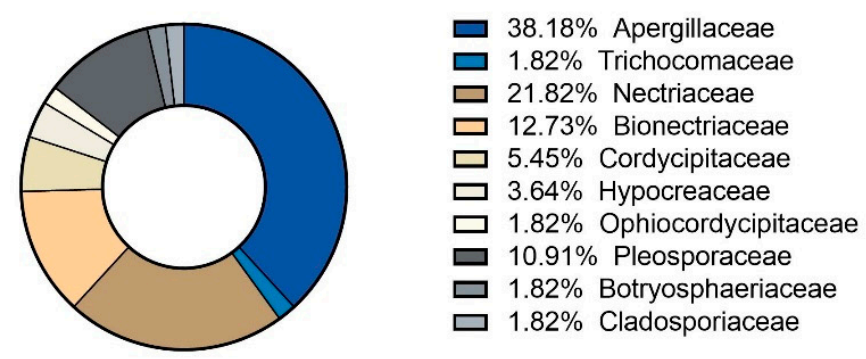

Figure 3. The relative abundance of fungal isolated according to (A) classes, (B) orders, and (C) families. 
Overall, the most common genera were Aspergillus in Cuma (60\%), Fusarium in Ercolano $(42.86 \%)$, Penicillium in Nola $(41.67 \%)$, Fusarium in Oplonti $(45.45 \%)$, Penicillium (60\%) in Pompei, Fauno, and Aspergillus (50\%) in Pompei, Castricio (Figure 4).

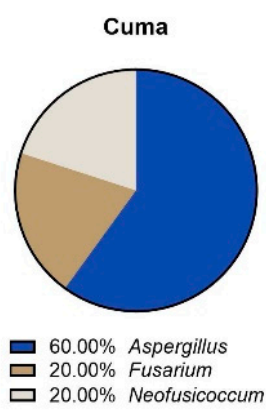

D

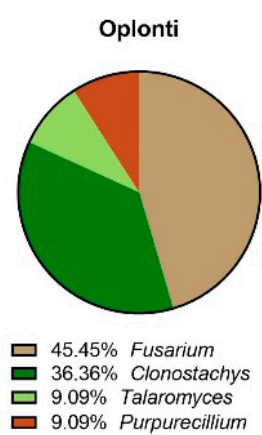

B

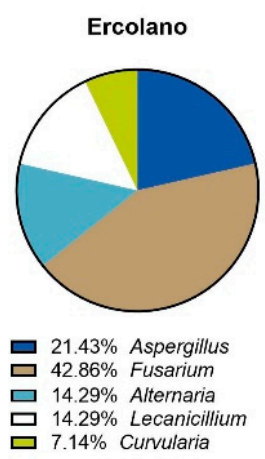

$\mathbf{E}$

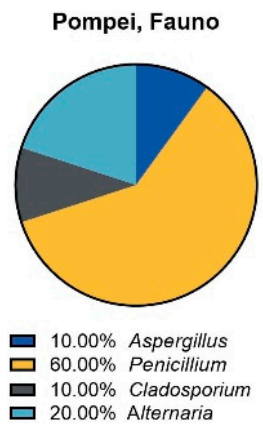

C

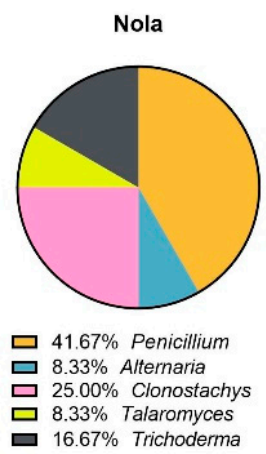

$\mathbf{F}$

Pompei, Castricio

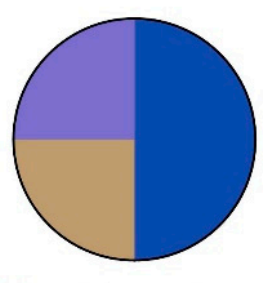

$50.00 \%$ Aspergillus

$25.00 \%$ Fusarium

口 $25.00 \%$ Lecanicillium

Figure 4. The relative prevalence of fungal genera found in: Sibyl Caves in Cuma (A), Suburban Baths in Ercolano (B), the Roman Amphitheater in Nola (C), the House of Poppea in Oplonti (D), and the House of Fauno (E) and the House of Castricio (F) in Pompei.

\section{Discussion}

The protection of cultural heritage often involves the study of the bio-receptivity of building materials and the biodegradation potential of microorganisms involved in deterioration, which can be primarily assessed through laboratory studies. In this work, a non-destructive method was used to sample microorganisms at UNESCO cultural heritage sites in Campania, Italy. In particular, we sampled using adhesive tape sampling coupled with microscopical analysis to identify the constituent microorganisms in biofilms of these monuments, which allows us to examine the existing relationships between the surface and the colonizing microorganisms [9]. The observations made using confocal light microscopy demonstrated fungal colonization in all the adhesive tape samples analyzed as a network of filamentous structures. Furthermore, we observed the presence of cyanobacteria and algae closely connected with filamentous structures, demonstrating that fungi actively colonize the rock as essential compounds of the biofilm sampled and not as contaminants. The isolation of fungi through culture-dependent methods, followed by maintenance of strains in culture, was aimed at obtaining quality-controlled isolates for further studies on biodeterioration processes and to develop innovative strategies for their control. For each strain, we collected data related to the substrate and environmental conditions at the sampling location and this information can be used to develop future laboratory experiments simulating specific environmental conditions under which these fungi can grow. Indeed, future perspectives are directed towards using our fungi as models to perform in vitro experiments for understanding the patterns of microbial colonization of 
stone materials [21]. The fungal isolates in this study are widespread, frequently associated with soil particles and plant material, which is probably due to their broad tolerance to different environmental conditions and allows them to colonize a large array of terrestrial habitats [27]. Molecular identification of sampled strains was performed using the internal transcribed spacer (ITS) rDNA area, which is the most widely used marker for fungi [19]. Unfortunately, for many Ascomycota genera, such as Penicillium and Aspergillus, the ITS is not variable enough to allow for species-level identification [28]. Because of the limitations associated with the chosen molecular marker, herein we considered the species-complex level for an overview of fungal diversity on stone monuments. We recognize the necessity of further identification using taxon-specific markers (e.g., SSRs) for identifying isolates to species level as the collection grows. The genera isolated in our sampling include Alternaria, Aspergillus, Cladosporium, Clonostachys, Curvularia, Fusarium, Lecanicillium, Neofusicoccum, Penicillium, Purpureocillium, Talaromyces, and Trichoderma, which are known to be ubiquitous filamentous fungi of soil and are often airborne. Some of them were already described as colonizer, or occasionally pioneer, taxa of deteriorated monuments [29]. For most of these species, there is no representative strain of the wide range of morphology and physiology expressed within that species and therefore it is necessary to maintain a number of representative strains. Some collections, such as the CABI Bioscience Genetic Resource Collection, retain on average five strains for each species, but in some cases this number is not sufficient. This is the case for host specificity in the plant pathogen, such as Fusarium oxysporum, which has a large number of genetic variants [30]. Thus, ex situ conservation of microorganisms collected from monuments can ensure that all strains with their unique properties are preserved and maintained over time. In accordance with other studies, we observed that the genera most frequently identified as colonizers of several stone substrates are Aspergillus, Fusarium, and Penicillium [31]. The action of these fungi, included in the orders Capnodiales and Pleosporales, could lead to aesthetic alteration and biopitting of stone materials [32]. Moreover, some of the fungal isolates belonging to Alternaria section Alternata, Cladosporium sp., Fusarium solani species complex, and Penicillium section Aspergilloides are known to contribute to acidification and the dissolution of stone by excreting organic acids. In particular, oxalic acid secreted by fungi can dissolve limestone calcium carbonate, producing calcium oxalates, one of the most severe biodeterioration processes affecting limestone monuments [33]. In addition, recently it has been shown that the genus Purpureocillium may have halotolerant characteristics [34], which may further broaden the impact these fungi have on stone structures.

\section{Conclusions}

The collection and molecular identification of fungal strains and their associated ecological data, describing their site of sampling, type of substrate, and morphological diagnostic characteristics, represent a key resource for the development of biotechnological approaches devoted to the conservation of cultural heritage. The ex situ conservation of fungi sampled from bio-deteriorated environments can ensure that isolates are preserved to maintain their integrity and long-term survival. This is essential for future research on the preservation of historical monuments, including the ecological differentiation of fungal communities according to sampling sites and the production of desirable end products applicable for bioremediation.

Author Contributions: Conceptualization, M.P. and A.D.M.; methodology, M.P.; software, M.P. and A.D.M.; validation, A.D.M., A.P. and A.D.N.; data curation, M.P.; writing-original draft preparation, M.P.; writing-review and editing, K.J.D., A.D.N. and A.P.; supervision, A.P. All authors have read and agreed to the published version of the manuscript.

Funding: This research received no external funding.

Institutional Review Board Statement: Not applicable.

Informed Consent Statement: Not applicable. 
Data Availability Statement: Data are contained within the article.

Acknowledgments: The authors thank the Herculaneum Archaeological Park, the Pompei Archaeological Park, the Phlegrean Fields Archaeological Park, Soprintendenza Archeologia Belle Arti e Paesaggio della città metropolitana di Napoli, and the Società dei Naturalisti in Napoli (Naples, Italy) for the assistance with research. The authors gratefully thank Serena Di Lecce and Alessandra Di Leva for their valuable technical support.

Conflicts of Interest: The authors declare no conflict of interest.

\section{References}

1. Salvadori, O.; Municchia, A.C. The Role of Fungi and Lichens in the Biodeterioration of Stone Monuments. Open Conf. Proc. J. 2016, 7, 39-54. [CrossRef]

2. Burford, E.P.; Fomina, M.; Gadd, G.M. Fungal involvement in bioweathering and biotransformation of rocks and minerals. Miner. Mag. 2003, 67, 1127-1155. [CrossRef]

3. Sterflinger, K. Fungi as Geologic Agents. Geomicrobiol. J. 2000, 17, 97-124. [CrossRef]

4. Wright, J.S. Geomorphology and stone conservation: Sandstone decay in Stoke-on-Trent. Struct. Surv. 2002, 20, 50-61. [CrossRef]

5. Turick, C.E.; Berry, C.J. Review of concrete biodeterioration in relation to nuclear waste. J. Environ. Radioact. 2016, 151, 12-21. [CrossRef] [PubMed]

6. Caneva, G.; Nugari, M.P.; Nugari, M.P.; Salvadori, O. Plant Biology for Cultural Heritage: Biodeterioration and Conservation; Getty Publications: Los Angeles, CA, USA, 2008.

7. Gaylarde, C.; Silva, M.R.; Warscheid, T. Microbial impact on building materials: An overview. Mater. Struct. 2003, 36, 342-352. [CrossRef]

8. Pinna, D. Biofilms and lichens on stone monuments: Do they damage or protect? Front. Microbiol. 2014, 5, 133. [CrossRef]

9. Urzì, C.; De Leo, F. Sampling with adhesive tape strips: An easy and rapid method to monitor microbial colonization on monument surfaces. J. Microbiol. Methods 2001, 44, 1-11. [CrossRef]

10. Larson, C.; Passy, S.I. Spectral fingerprinting of algal communities: A novel approach to biofilm analysis and biomonitoring. J. Phycol. 2005, 41, 439-446. [CrossRef]

11. Samson, R.A.; Hoekstra, E.S.; Frisvad, J.C.; Filtenborg, O. Introduction to Food-Borne Fungi; Centraalbureau voor Schimmelcultures: Delft, The Netherlands, 1996.

12. Nichols, H.W.; Bold, H.C. Trichosarcina polymorpha Gen. et Sp. Nov. J. Phycol. 1965, 1, 34-38. [CrossRef]

13. Jeger, M.J.; Lamour, A.; Gilligan, C.A.; Otten, W. A fungal growth model fitted to carbon-limited dynamics of Rhizoctonia solani. New Phytol. 2008, 178, 625-633. [CrossRef] [PubMed]

14. Skaar, I.; Stenwig, H. Malt-yeast extract-sucrose agar, a suitable medium for enumeration and isolation of fungi from silage. Appl. Environ. Microbiol. 1996, 62, 3614-3619. [CrossRef]

15. Passarini, M.R.Z.; Santos, C.; Lima, N.; Berlinck, R.G.S.; Sette, L.D. Filamentous fungi from the Atlantic marine sponge Dragmacidon reticulatum. Arch. Microbiol. 2012, 195, 99-111. [CrossRef] [PubMed]

16. Barnett, H.L.; Hunter, B.B. Illustrated Genera of Imperfect Fungi, Mycol, 3rd ed.; Burgess Publishing Company: Minneapolis, MN, USA, 1972.

17. Bushell, M.E. (Ed.) Fassatiovà O Moulds and filamentous fungi in technical microbiology. In Progress in Industrial Microbiology 22; Elsevier: Amsterdam, The Netherlands, 1986.

18. Doyle, J. DNA Protocols for Plants. In Molecular Techniques in Taxonomy; Springer: Berlin/Heidelberg, Germany, 1991; pp. 283-293. [CrossRef]

19. Schoch, C.L.; Seifert, K.A.; Huhndorf, S.; Robert, V.; Spouge, J.L.; Levesque, C.A.; Chen, W.; Fungal Barcoding Consortium. Nuclear ribosomal internal transcribed spacer (ITS) region as a universal DNA barcode marker for Fungi. Proc. Natl. Acad. Sci. USA 2012, 109, 6241-6246. [CrossRef] [PubMed]

20. Walther, G.; Pawłowska, J.; Alastruey-Izquierdo, A.; Wrzosek, M.; Rodriguez-Tudela, J.; Dolatabadi, S.; Chakrabarti, A.; De Hoog, G. DNA barcoding in Mucorales: An inventory of biodiversity. Pers. Mol. Phylogeny Evol. Fungi 2013, 30, 11-47. [CrossRef]

21. Del Mondo, A.; Pinto, G.; De Natale, A.; Pollio, A. In vitro colonization experiments for the assessment of mycelial growth on a tuff substratum by a fusarium solani strain isolated from the Oplonti (Naples, italy) archaeological site. Int. J. Cons. Sci. 2017, 8, 651-662.

22. Smith, D.; Ryan, M.J.; Day, J.G. The UKNCC Biological Resource: Properties, Maintenance and Management; UKNCC Secretariat: Egham, UK, 2001; 382p.

23. OECD. Biological Resource Centres: Underpinning the Future of Life Sciences and Biotechnology; OECD Publications: Paris, France, $2001 ;$ p. 66.

24. D'Elia, L.; Del Mondo, A.; Santoro, M.; De Natale, A.; Pinto, G.; Pollio, A. Microorganisms from harsh and extreme environments: A collection of living strains at ACUF (Naples, Italy). Ecol. Quest. 2018, 29, 1-16. [CrossRef]

25. Gorbushina, A.A. Life on the rocks. Environ. Microbiol. 2007, 9, 1613-1631. [CrossRef]

26. Warscheid, T.; Braams, J. Biodeterioration of stone: A review. Int. Biodeterior. Biodegrad. 2000, 46, 343-368. [CrossRef] 
27. Isola, D.; Zucconi, L.; Onofri, S.; Caneva, G.; De Hoog, G.S.; Selbmann, L. Extremotolerant rock inhabiting black fungi from Italian monumental sites. Fungal Divers. 2016, 76, 75-96. [CrossRef]

28. Seifert, K.A.; Samson, R.A.; Dewaard, J.R.; Houbraken, J.; Lévesque, C.A.; Moncalvo, J.-M.; Louis-Seize, G.; Hebert, P.D.N. Prospects for fungus identification using CO1 DNA barcodes, with Penicillium as a test case. Proc. Natl. Acad. Sci. USA 2007, 104, 3901-3906. [CrossRef] [PubMed]

29. Del Mondo, A.; De Natale, A.; Pinto, G.; Pollio, A. Correction to: Novel qPCR probe systems for the characterization of subaerial biofilms on stone monuments. Ann. Microbiol. 2019, 69, 1097-1106. [CrossRef]

30. Kirk, P.M.; Cannon, P.F.; David, J.C.; Stalpers, J.A. Dictionary of the Fungi, 9th ed.; CABI Publishing: Wallingford, UK, $2001 ;$ p. 55.

31. Saarela, M.; Alakomi, H.-L.; Suihko, M.-L.; Maunuksela, L.; Raaska, L.; Mattila-Sandholm, T. Heterotrophic microorganisms in air and biofilm samples from Roman catacombs, with special emphasis on actinobacteria and fungi. Int. Biodeterior. Biodegrad. 2004, 54, 27-37. [CrossRef]

32. Sterflinger, K. Fungi: Their role in deterioration of cultural heritage. Fungal Biol. Rev. 2010, 24, 47-55. [CrossRef]

33. Gadd, G.M. Geomycology: Biogeochemical transformations of rocks, minerals, metals and radionuclides by fungi, bioweathering and bioremediation. Mycol. Res. 2007, 111, 3-49. [CrossRef] [PubMed]

34. Arpini, C.M.; Nóbrega, Y.C.; Castheloge, V.D.; Neves, D.S.; Tadokoro, C.E.; Da Costa, G.L.; Oliveira, M.M.E.; Santos, M.R.D.D. Purpuriocillium lilacinum infection in captive loggerhead sea turtle hatchlings. Med Mycol. Case Rep. 2019, 23, 8-11. [CrossRef] 